\title{
Advanced Hot Section Materials and Coatings Test Rig
}

Report: Phase 1 Final Report

Reporting Period Start Date: 10/01/03

Reporting Period End Date: 10/31/04

Principal Author: Dan Davies

Report Date: December 20, 2004

DOE Award Number: DE-FC26-03NT41888

Florida Turbine Technologies, Inc.

140 Intracoastal Pointe Drive, Suite 301

Jupiter, FL 33477 
"This report was prepared as an account of work sponsored by an agency of the United States Government. Neither the United States Government no any agency thereof, nor any of their employees, makes any warranty, express or implied, or assumes any legal liability or responsibility for the accuracy, completeness, or usefulness of any information, apparatus, product, or process disclosed, or represents that its use would not infringe privately owned rights. Reference herein to any specific commercial product, process, or service by trade name, trademark, manufacturer, or otherwise does not necessarily constitute or imply its endorsement, recommendation, or favoring by the United States Government or any agency thereof. The views and opinions of authors expressed herein do not necessarily state or reflect those of the United States Government or any agency thereof." 


\begin{abstract}
:
Phase I of the Hyperbaric Advanced Hot Section Materials \& Coating Test Rig Program has been successfully completed. Florida Turbine Technologies has designed and planned the implementation of a laboratory rig capable of simulating the hot gas path conditions of coal gas fired industrial gas turbine engines. Potential uses of this rig include investigations into environmental attack of turbine materials and coatings exposed to syngas, erosion, and thermal-mechanical fatigue.

The principle activities during Phase 1 of this project included providing several conceptual designs for the test section, evaluating various syngas-fueled rig combustor concepts, comparing the various test section concepts and then selecting a configuration for detail design. Conceptual definition and requirements of auxiliary systems and facilities were also prepared. Implementation planning also progressed, with schedules prepared and future project milestones defined. The results of these tasks continue to show rig feasibility, both technically and economically.
\end{abstract}




\section{Table of Contents:}

List of Graphical Materials

Executive Summary

Introduction

Experimental

Results and Discussion

Conclusion

Appendix 


\section{List of Graphical Materials:}

Figure 1. HADES Rig System Diagram

Figure 2. Conceptual design with parallel, transversely-mounted specimens

Figure 3. Conceptual design with radial, transversely-mounted specimens

Figure 5. Conceptual design with axial, parallel-mounted specimens

Figure 6. Schematic representations of test section conceptual designs

Figure 7. Conceptual design with axial, parallel-mounted specimens

Figure 8. Radial jet combustor concept

Figure 9. Prototype rig showing functional modules

Figure 10. Prototype rig test section flow streams

Figure 11. TMF Loading module

Figure 12. Rotation module showing magnetic drive coupling

Figure 13. Water quenched exhaust section

Figure 14. Air Compressor and Preheater

Figure 15. Schematic Diagram of Air Supply System

Figure 16. Schematic Diagram of Fuel Supply System

Figure 17. LabVIEW Virtual Instrument Control Panel \& Diagram

Figure 18. Pressure drop and airflow predictions for nominal operating conditions

Figure 19. TBC and substrate temperature predictions for a potential specimen design

Figure 20. Rig operating cost estimates based on 12 specimens per rig

Figure 21. Preliminary specifications for HADES rig test facility

Figure 22. HADES project plan for the DOE Financial Assistance Agreement 


\section{EXECUTIVE SUMMARY}

Phase I of the Hyperbaric Advanced Hot Section Materials \& Coating Test Rig Program has been successfully completed. Florida Turbine Technologies has designed and planned the implementation of a laboratory rig capable of simulating the hot gas path conditions of coal gas fired industrial gas turbine engines. Potential uses of this rig include investigations into environmental attack of turbine materials and coatings exposed to syngas, erosion, and thermal-mechanical fatigue.

The results of tasks conducted during this phase continue to show rig feasibility, both technically and economically. Principle activities were studies to determine the overall configuration of the rig, initial detail designs for the rig test section, and updates to the rig performance and cost estimates. Other tasks performed considered the recovery of waste heat to further reduce rig operating costs, provided preliminary definition of the rig air supply, fuel supply, facility requirements, and rig controls. Implementation planning progressed, with schedules prepared and future project milestones defined. 


\section{INTRODUCTION}

This is the final report of technical progress on Phase I of contract \# DE-FC2603NT41888 for the Hyperbaric Advanced Hot Section Materials \& Coating Test Rig which I was awarded to Florida Turbine Technologies (FTT) in October 2003. The objectives of Phase I were to complete conceptual design studies, downselect a configuration, and execute a detail design of the rig test section. Additional goals of this phase included conceptual definition of auxiliary systems and facilities, and preparation of plans for permitting and implementation of the test facility. In Phase II, a prototype test section will be fabricated and tested, and designs for auxiliary systems and facilities completed, and rig hardware fabricated, equipment purchased, and tests facilities constructed. Phase III completes the project with the installation of the rig, checkout and demonstration.

The rig system diagram shown in Figure 1 incorporates a syngas combustor operating at $\mathrm{G}$ class IGT temperature and pressure conditions, coupled to a test section capable of testing multiple specimens concurrently. The test specimens are to be air cooled by internal convection to produce a range of thermal load conditions on the of test specimen substrate and coating. The rig is also to be capable of applying a static mechanical load to the specimens, simulating the centrifugal and gas bending forces on turbine blades. The intent is that the rig be capable of operating with variations in parameters such as temperature, mean stress, frequency and dwell time in order assess the effects on thermal mechanical fatigue (TMF) of the material specimen. Instrumentation to monitor actual test conditions and to detect specimen failure is also to be evaluated.

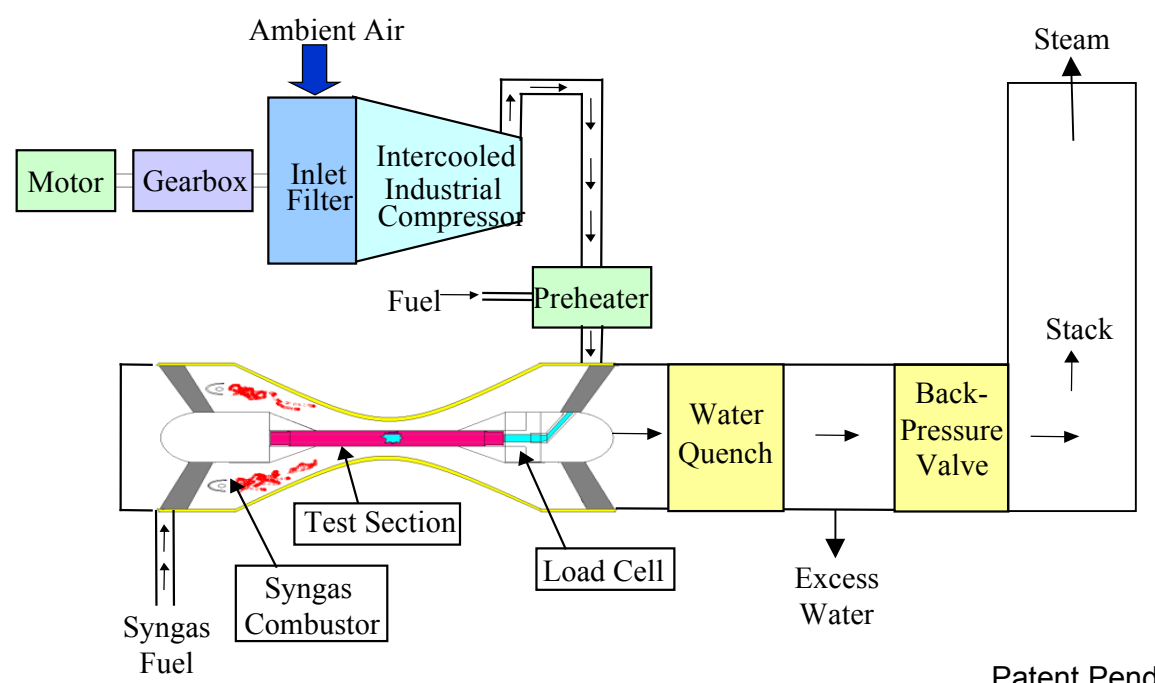

Patent Pending

Figure 1. HADES Rig System Diagram 


\section{EXPERIMENTAL}

This project provides for the design and implementation of a laboratory rig capable of simulating the hot gas path conditions of coal gas fired industrial gas turbine engines. Potential uses of this rig include investigations into environmental attack of turbine materials and coatings exposed to syngas, erosion, and thermal-mechanical fatigue. Because this phase of the program provided only conceptual and detail design definition, there are no experimental methods or data to report on at this time.

\section{RESULTS AND DISCUSSION}

Specific tasks worked during Phase 1 focused on completing the conceptual design of the overall test rig, followed by detail design of the test section. Data deliverables from this phase and the corresponding task number assigned in the proposal were as follows:

- Test Section Conceptual Design (Task 1.4)

- Combustor Conceptual Design (Task 1.3)

- Test Section Detailed Design (Task 1.5)

- Exhaust System \& Heat Recovery System Design and Int. Studies (Task 1.2,1.8)

- Air Supply System Definition (Task 1.6)

- Syngas / Natural Gas Fuel System Conceptual Design (Task 1.7)

- Instrumentation and Controls (Task 1.10)

- Rig Performance/Energy Cost Analysis Update (Task 1.1)

- Detailed Cost Estimate (Task 1.11)

- Facility Requirements Definition (Task 1.9)

- Permitting Assessment and Plan (Task 1.12)

- Implementation Plan (Task 1.13)

A summary of results for each of these tasks follows.

\section{Test Section Conceptual Designs}

Several conceptual designs were investigated which were to accommodate testing of multiple specimens arranged transverse to the combustor exhaust. A downselect was held to select a single configuration for detail design and application into the prototype test rig. The first three described in this report were developed under this cost share program and feature transversely oriented test specimens intended to simulate leading edge impingement of hot gas on a turbine airfoil. The fourth was developed under the SBIR grant DE-FG02-03ER83660, and features a test section oriented axially to the combustor exhaust. 
A transverse-parallel test section configuration is shown in Figure 2. This concept has multiple specimens arranged parallel to each other, all mounted transverse to the hot gas flow. The test section consists of a combustor, a test section housing and an exhaust chamber. The air supply for the rig is from an electric motor-driven industrial compressor. In this arrangement, compressed air is routed through each of the cylindrical specimens for internal cooling then collected in a combustor plenum to be used for combustor cooling and then in the combustion process. Hot gas accelerates as it exits the combustor and flows through one or more rows of test specimens.

This concept has the advantage of simulating the leading edge of turbine airfoils, as the hot gas impinges on the tubular specimens then flows around either side. Several disadvantages, however, are found with this arrangement. Because the gas velocity and pressure varies around the cylinders, the heat load, and thus coating and substrate temperatures will not be uniform. Circumferential thermal gradients in the specimens will result in stress components that can have a significant impact on coating life. While it is recognized that similar variation exists in actual engine components, this is undesirable in the test rig since it contributes to experimental and analytical uncertainty as to the actual conditions a given specimen has been subjected to. Another disadvantage is that due to combustor pattern factor, gas temperature will be different on each test specimen. Without measurement of local conditions on each specimen, this also contributes to experimental uncertainty. Leakage of cooling air between the specimen and test section shrouds adds to the temperature uncertainty, but also increases the operating cost as the rig inlet flow must be increased to achieve the same combustor operating conditions. The leakage estimate for a configuration having just seven test specimens is $16.8 \%$. Applying a tensile load on an individual transverse test specimen is not as difficult as in the axial concepts studied, however, it is unlikely that a uniform tensile force can be applied to a number of specimens simultaneously.

See Appendix

Figure 2. Conceptual design with parallel, transversely-mounted specimens 
A second transverse test section configuration is shown in Figure 3 . This series arrangement has multiple specimens stacked end-to-end along the same axis. Also in this configuration, compressed air is routed through the cylindrical specimens for internal cooling then is collected in a combustor plenum to be used for combustor cooling and then in the combustion process. Hot gas accelerates as it exits the combustor and flows over the stack of specimens positioned transversely across the combustor exit.

This concept also has the advantage of simulating the leading edge of turbine airfoils, as the hot gas impinges on the tubular specimens then flows around either side. Leakage of cooling air between the specimen and test section shrouds is greatly reduced relative to the parallel arrangement, as just two seals are now needed, resulting in an estimated leakage of just $2.4 \%$. The problem of applying uniform tensile force to each specimen is also eliminated, as a single device can be used to load the entire stack of specimens simultaneously. There are also some disadvantages seen with this arrangement. Once again, because the gas velocity and pressure varies around the cylinder, heat load, and thus coating and substrate temperatures will not be uniform. As in the parallel arrangement, such variation is undesirable since it contributes to experimental and analytical uncertainty. Combustor pattern factor is also an issue, as gas temperature will be different on each test specimen.

See Appendix

Figure 3. Conceptual design with series, transversely-mounted specimens

Another transverse specimen arrangement considered a radial orientation of test specimens about the centerline of a can combustor exhaust duct. The end of the duct would be capped, forcing exhaust gas to flow radially outboard between the tubular test specimens as shown schematically in Figure 4. 
The advantage of this concept over the parallel arrangement is that it eliminates the need for a circular to rectangular transition section between combustor and test section. All test locations are also identical, with no locations where the exhaust gas flows between a cylindrical specimen and a test section wall. Disadvantages are, however, that because combustion exhaust gases are not accelerated through a nozzle, the cylinder leading edges do not experience high impingement velocity. Again in this configuration, because gas velocity and pressure varies around the cylinder, heat load, and thus coating and substrate temperatures will not be uniform. Combustor pattern factor is again an issue, as gas temperature flowing around each cylinder may be different, although it is likely better than in configurations requiring multiple fuel nozzles or transition sections. Leakage of cooling air between the specimen and test section endwalls is also worse, with $20 \%$ estimated for this arrangement of eight test specimens. Also similar to the parallel arrangement, applying a uniform tensile force to each specimen will be very difficult.

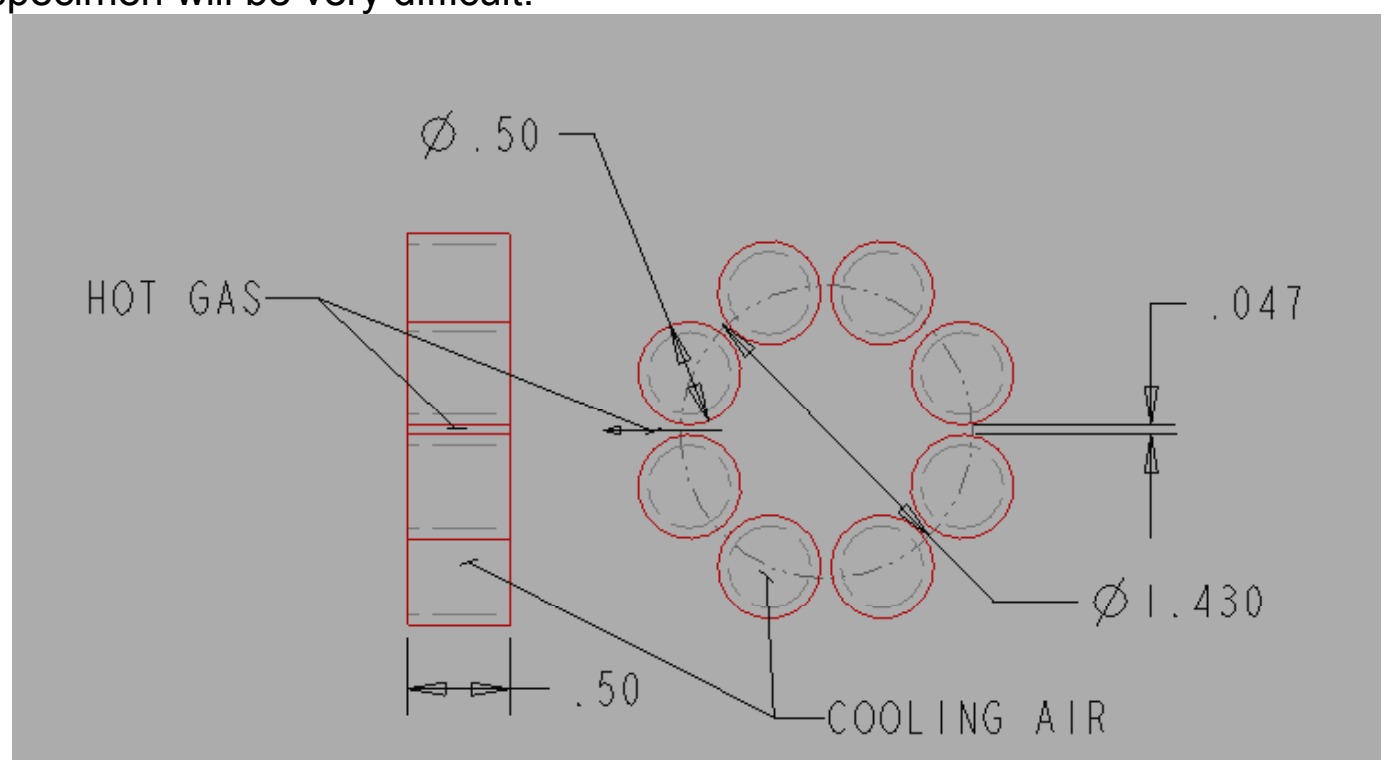

Figure 4. Conceptual design with radial, transversely-mounted specimens

The axial configuration is similar to the earlier arrangements in that a cylindrical test specimen is used and is internally cooled with the same compressed air that is later used in the combustion process. Figure 5 shows the axial-series concept that features a tubular test section that contains the hot gas within a small annular gap around the stack of test specimens.

The principle advantage of this arrangement is it offers predictable heat transfer along the entire length of specimens. Having a uniform annular gap, the hot gas velocity is uniform around the circumference, thus assuming a constant combustor temperature, there is no difference in heat load around the specimen. The effect combustor pattern 
factor can be mitigated by rotating the stack of specimens so that the entire specimen is exposed to a time-averaged temperature. The main disadvantage of this scheme is that any heat loss to the test section results in a lower gas temperature on each subsequent test specimen. Cooling air leakage is minimal in this arrangement, as just two seals are needed, resulting in an estimated leakage of just $2.4 \%$. A uniform tensile force can be applied to each specimen as a single device loads the entire stack of simultaneously.

See Appendix

Figure 5. Conceptual design with axial, parallel-mounted specimens

For the purpose of comparing these different concepts, comparable configurations shown in Figure 6 were developed based on 0.5 in diameter cylindrical specimens with internal air cooling, exposed to the hot gas on the external surface. Specimen length was assumed to be 0.5 in. A maximum number of specimens is included in each configuration, all having the same effective area and assumed pressure drop to result in an equivalent airflow of $0.4 \mathrm{pps}$.

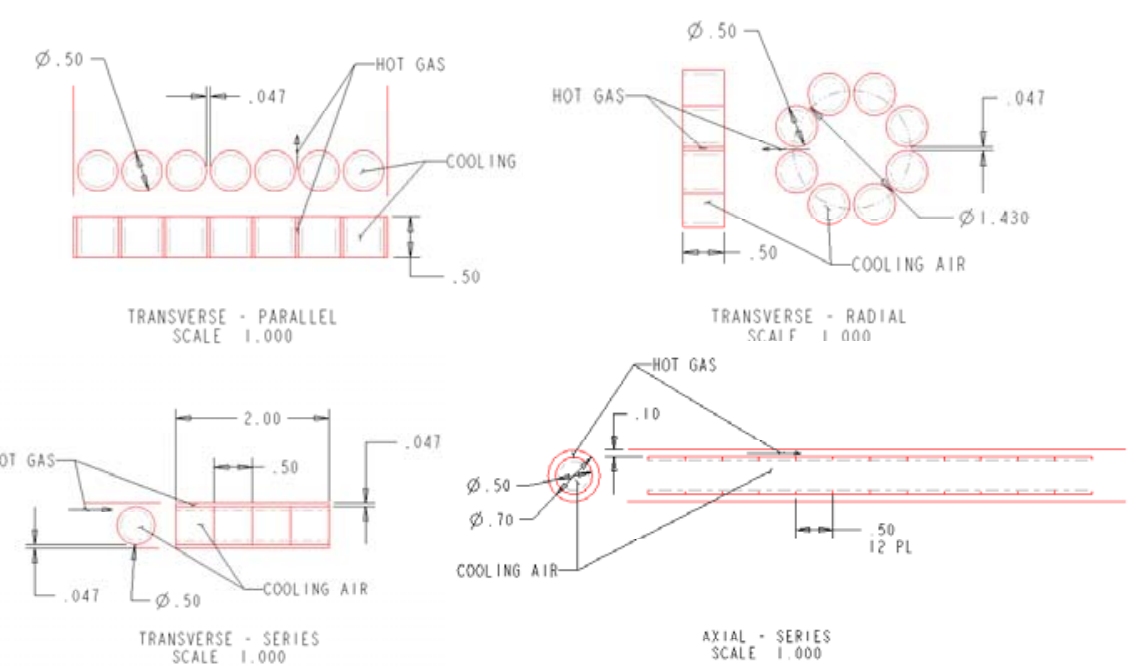

Figure 6. Schematic representations of test section conceptual designs 
Key Success Factors (KSFs) were identified for the materials test rig design. KSFs are scored $5=$ =best to $1=$ =worst. Weighing factors are also assigned for each KSF; $3=$ most important, 1=least important.

- Number of test specimens

The number of individual material test specimens that can be included in the same test. A rig design having the greatest number of specimens, without excessive penalty to other KSFs is preferred. Weighing factor: 3

- Thermal Loading

Heat transfer to the test specimens should be uniform, predicable, measurable, and representative of thermal loading on gas turbine components. Weighing factor: 3

- Mechanical Loading

For thermal-mechanical fatigue (TMF) testing, a tensile load is applied to the test specimens. The load should be uniform, predicable, measurable, and representative of tensile loading on rotating gas turbine components. Weighing factor: 2

- Leakage

Air loss, bypassing the intended flow circuit should be minimized. Includes loss of cooling air between specimens and the rig walls or between specimens and adjoining specimens. Also includes loss of air between the combustor and test section. Weighing factor: 2

- Simplicity

In maximizing rig performance and reliability, simplicity can be maintained in regard to attributes such as number and cost of parts, test set-up time and procedures, reliability and safety. Weighing factor: 1

An analysis of the four potential rig configurations relative to the KSFs yielded the results shown in "spider chart" format in Figure 7.

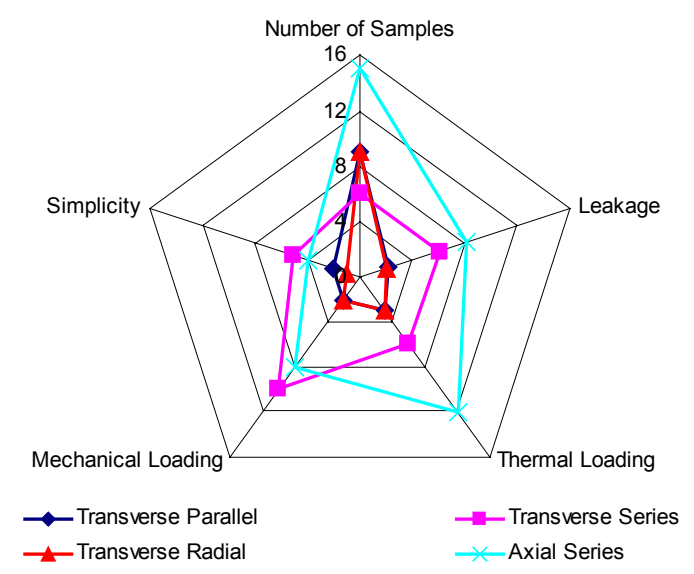

Figure 7. Conceptual design with axial, parallel-mounted specimens 
The axial - series arrangement was identified as the preferred configuration for the materials test rig. The transverse - series configuration shown to be slightly better on two KSFs, but significantly worse on the other three. Transverse - parallel, and transverse - radial scored lower than axial - series on all other KSFs.

All three transversely arranged test specimens were found inferior in the thermal loading comparison. The disadvantage of these transverse arrangements is that the flow over the cylinder is complex and difficult both to predict and to experimentally measure. The fundamental issue with aerodynamics and heat transfer from flow around a single cylinder in cross flow is that there is a large variation in the boundary layer around the cylinder. Unlike with the well behaved flow in a tube as in the axial - series configuration, pressure gradients that result from cross flow over the tube result in flow separation. The location where this separation occurs is a function of Reynolds number and flow rate. For a fixed test section geometry and sample size, the heat transfer characteristics will vary depending on flow rate. This makes analytical scaling difficult and leads to large errors in data reduction. At high Reynolds numbers there will be two inflection points in the specimen heat transfer coefficient over the cylinder. The first inflection comes from a transition from laminar to turbulent flow, and the second is related to the separation point on the cylinder. Heat flux through the material, thus the substrate and coating temperatures, will vary with the local heat transfer coefficient. Empirical data is available from which the average and local variations in heat transfer can be calculated, however, in the tests planned for this rig, such variation is considered highly undesirable.

Specimen rotation has been considered as a potential solution to produce a more uniform heat flux around the specimen. The speed of rotation needs to be faster than the thermal time constant for the material system being tested. If the rate of rotation is too great, however, further heat transfer variation may be induced due to aerodynamic effects of rotating cylinders in crossflow.

Based upon the results of the combustor and test section conceptual design effort, the axial-series test section configuration was selected as having the minimum per specimen test cost with the most desirable thermal loading.

\section{Combustor Conceptual Design}

Conceptual design studies for a rig combustor fueled by syngas was conducted. Two approaches were considered for the burner: 1) scaling an existing natural gas burner modified to burn syngas, and 2) developing a new, rig unique combustor with gas nozzles sized for syngas and natural gas. For the existing design approach, a Siemens V64.3A burner was considered. In this 70MW engine, airflow to an individual burner is over $5 \mathrm{lb} / \mathrm{sec}$, significantly oversized for an unscaled application in this rig having a target total airflow below $0.5 \mathrm{lbs} / \mathrm{sec}$. Scaling the burner geometry to this smaller airflow 
is possible, however, such a significant redesign is not expected to yield similar performance, stability and emissions without substantial development. The rig-unique combustor approach is to adapt an existing FTT radial jet combustor design to operate on syngas. A model of this air-cooled combustor design is shown in Figure 8. Sized for a nominal airflow of $0.5 \mathrm{pps}$, the combustor has swirlers oriented radially around the outer liner to $\mathrm{mix} 30 \%$ of the airflow with fuel from the 6 gas nozzles. To convert this design from natural gas to syngas operation, the 18 tip holes on these nozzles need to be made larger (from 0.016 diameter to 0.024 ).

See Appendix

Figure 8. Radial jet combustor concept

\section{Test Section Detailed Design}

Based on the configuration downselect decision, detail design activity was initiated on the axial series rig concept. Shown in Figure 9, the rig consists of six modules that enable operation over the desired range of conditions, providing predictable and repeatable test conditions.

See Appendix

Figure 9. Prototype rig showing functional modules 
Shown in Figure 10, air enters the rig test section on the right-hand side and flows within the test specimen toward the combustor section. This air internally cools the test specimen, then is diffused after passing through the combustor, and is collected in the combustor plenum. A portion of this air is used to impingement cool the combustor liner, after which it is used for dilution air in the combustion process. The remainder of the air flows directly into the combustion chamber through swirlers located about each of the six gas nozzles.

See Appendix

Figure 10. Prototype rig test section flow streams

Hot gas exiting the combustor flows through a convergent section, then into a constantarea test section. Gas within the test section is contained by closed-circuit water-cooled vessel having channels machined lengthwise along the outer surface. Copper beryllium material was selected for this component due to good strength and for lower thermal stress resulting from the high thermal conductivity of the material. At the end of the test section, the flow is diffused slightly, then dumped into the exhaust section. Water mist injected into the exhaust section flashes to steam and quenches the hot gas stream prior to passing through a backpressure valve.

To enable thermal-mechanical fatigue (TMF) testing a tensile load can be applied along the length of test specimen. Shown in Figure 11, with the test specimen axially fixed at the thrust bearing, an axial force can be generated within the load module by controlling the differential air pressure across a piston. The piston is contained within an isolation compartment in order to use a cooler air supply, enabling the use of low-temperature materials for more effective sealing. 
In order to attain circuferentially uniform temperature loading conditions, the rig includes a rotation module to mitigate combustor pattern factor effects. This required the use of a thrust bearing at one end, a roller bearing at the other end, and a number of rotating seals along the length of the shaft. A magnetic drive coupling is used to allow the drive motor to be external to the rig and avoid penetrating the pressure vessel with a rotating shaft, as shown in Figure 12.

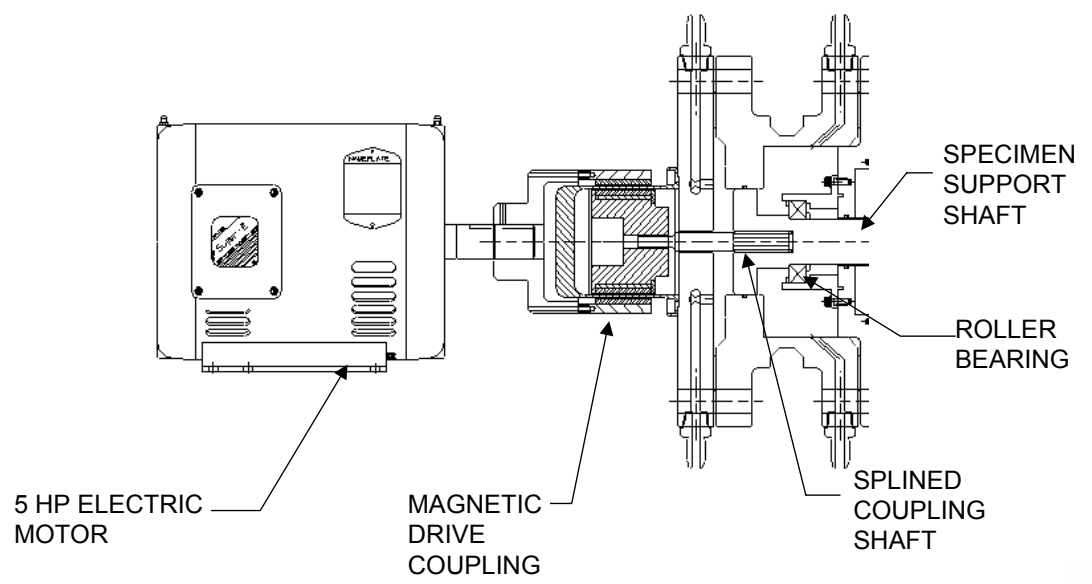

Motor Conservatively Sized to Overcome Est. Startup Torque of $36 \mathrm{ft}-\mathrm{lb}$ due to Bearings and Seals

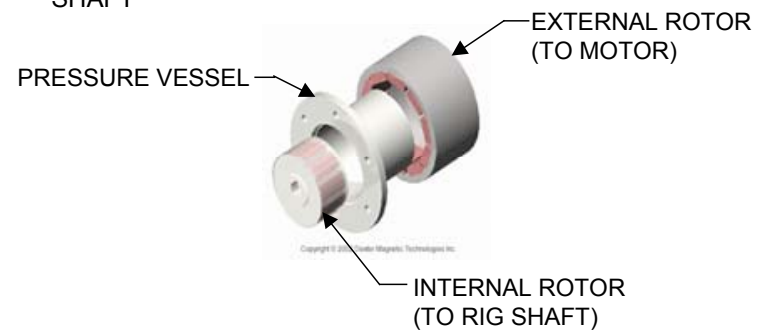

Magnetic Drive Coupling Eliminates Need for a High-Pressure Rotary Seal

Figure 12. Rotation module showing magnetic drive coupling

\section{Exhaust System \& Heat Recovery System Design and Integration Studies}

Concepts for the recovery of exhaust heat to reduce testing cost were considered. One potential use is for preheating of the rig inlet air exiting the compressor. Another use is as a heat source for a heat recovery steam generator (HRSG) that would supply steam to the host site. Neither of these approaches was adapted at this phase of the design, but could be considered at a later time as actual rig operating costs and availability are better understood.

Any exhaust system design is required to maintain pressure on the rig test section by throttling the flow through a backpressure valve. With stainless steel construction, gas flowing through the valve needs to be kept below $\sim 1000 \mathrm{~F}$. While the heat recovery 
concepts would meet this criterion, a system without an exhaust stream heat exchanger requires another method of reducing the exhaust gas temperature.

The design for the prototype rig exhaust section is shown in Figure 13. This component features a conical quenching support fitted with misting nozzles cool the flow to $\sim 600 \mathrm{~F}$, requiring a water flow rate of 3 gallons per minute.

See Appendix

Figure 13. Water quenched exhaust section

\section{Air Supply System Definition}

Compressed air to the rigs will be supplied by an Ingersoll-Rand Centac, 3 Stage, Intercooled Centrifugal Compressor, Model No. 2C1140M3. This compressor has a discharge capacity of 3136 SCFM at a pressure of 350 PSIG. Shown in Figure 14, this compressor is driven by a Siemens $1500 \mathrm{Hp}, 4160 \mathrm{~V}$ Electric Motor.

A bank of $4,50 \mathrm{~kW}$ air preheaters, also seen in Figure 14 will be used to heat the compressor discharge air prior to entering the test section. This heater can preheat the inlet air to nearly $1000 \mathrm{~F}$, and are rated to 350psi. A schematic diagram of the entire air supply system is seen in Figure 15. 


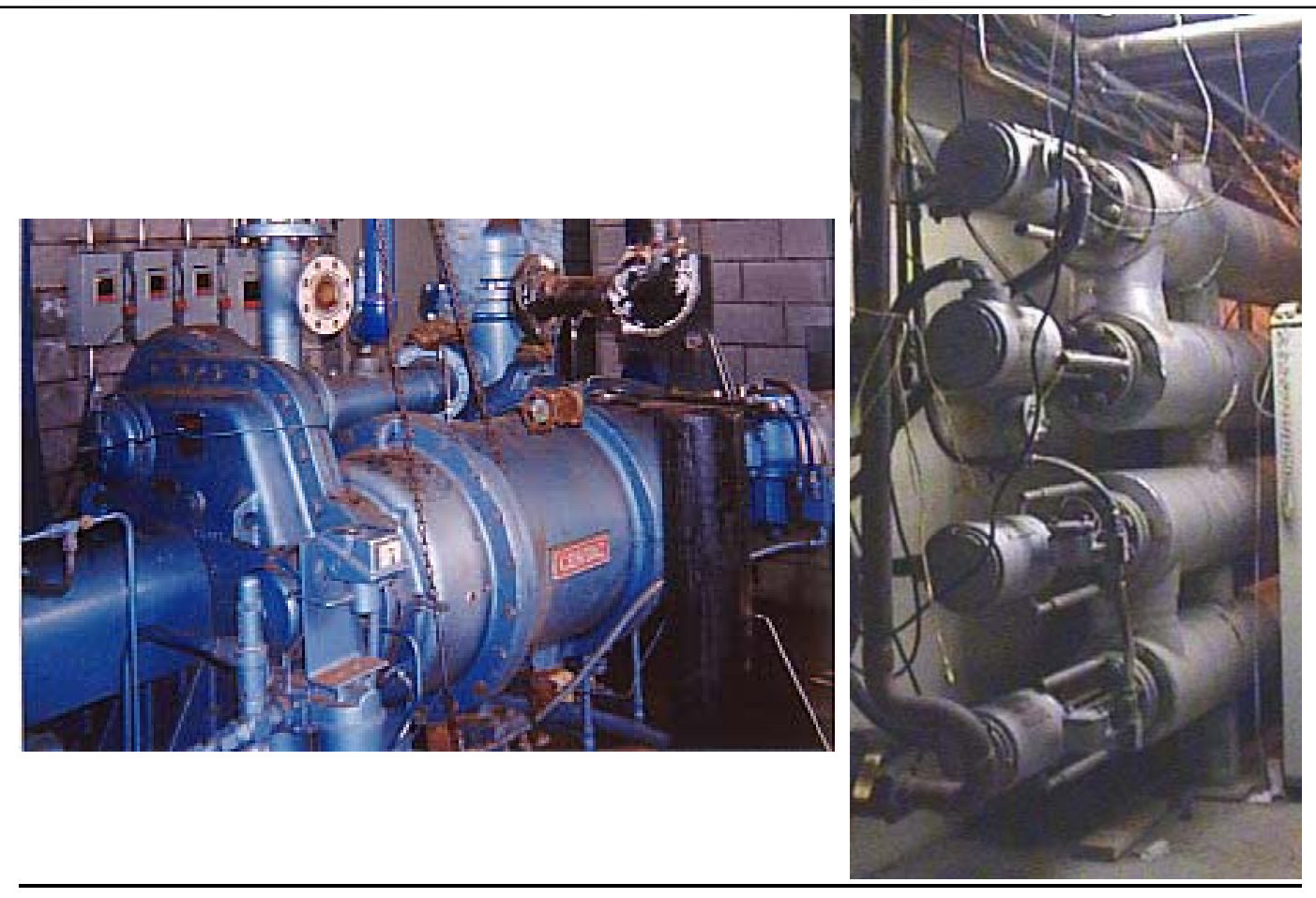

Figure 14. Air Compressor and Preheater

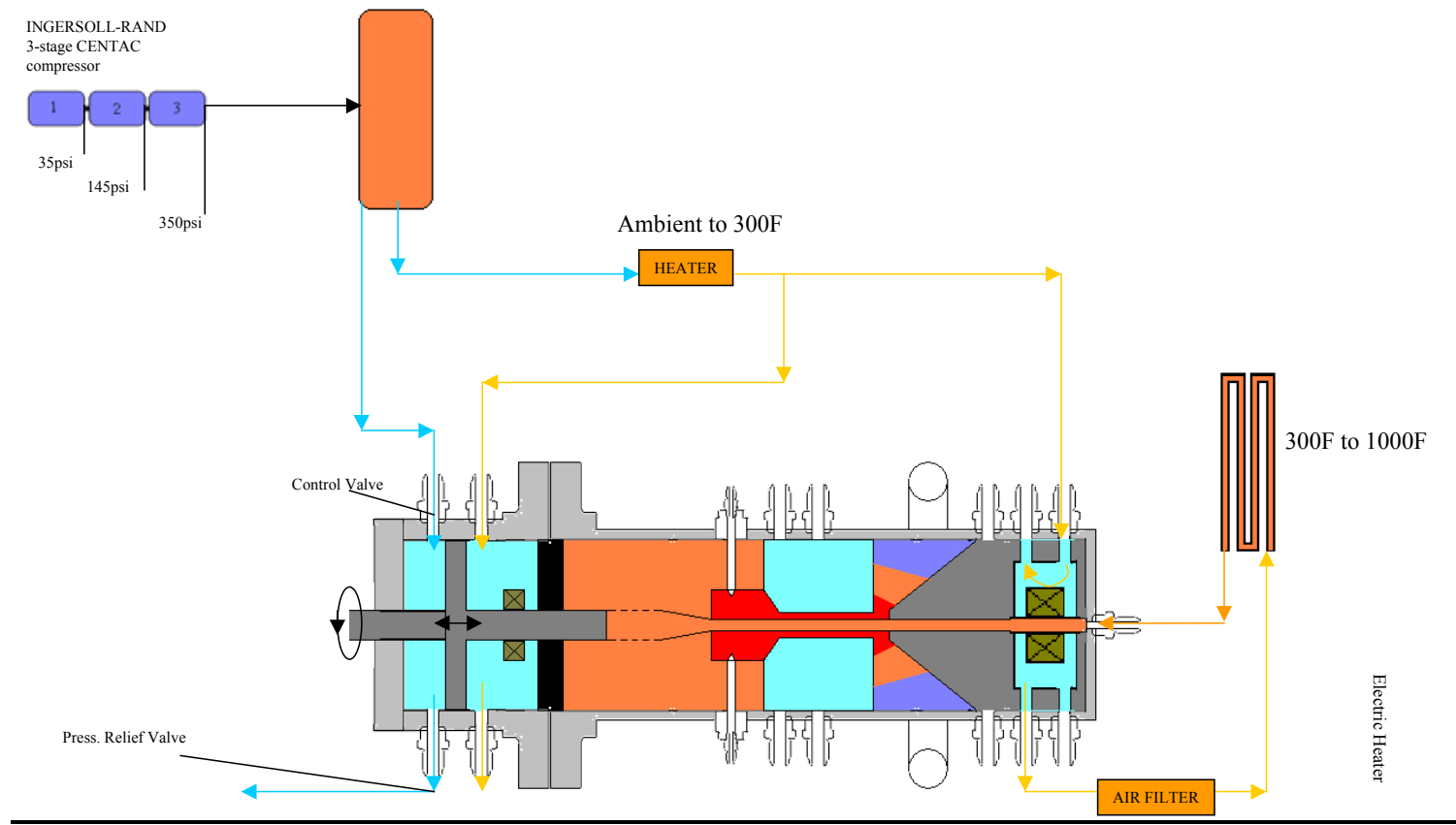

Figure 15. Schematic Diagram of Air Supply System 


\section{Syngas / Natural Gas Fuel System Conceptual Design}

The test facility can be setup to operate the rigs on various gaseous fuels. One concept for the rig test cells is shown in Figure 16. Each rig will have a dedicated control system. The maximum fuel flow is expected to be $\sim 64 \mathrm{pph}$ per rig at a maximum supply pressure of 525 psia.

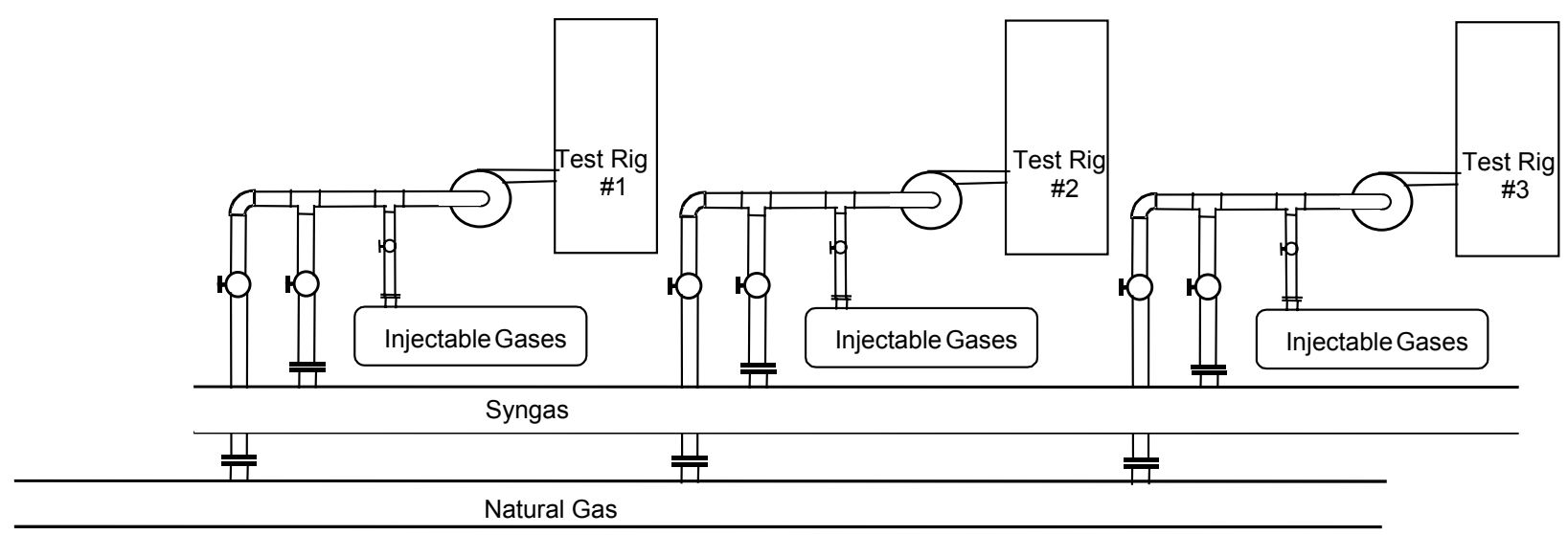

Figure 16. Schematic Diagram of Fuel Supply System

\section{$\underline{\text { Instrumentation and Controls }}$}

Rig control and health monitoring instrumentation requirements have been identified. Included are the inlet and exit, pressure and temperature for each flow stream: air, fuel and cooling water. The rig control plan is to set an airflow level and pressure using air control valves and venturi nozzles, then adjust fuel flow to attain the fuel/air ratio corresponding to the desired combustor and test section exit temperature. Thermocouples will also be placed on critical components to monitor conditions that could adversely impact rig life.

A preliminary configuration of a LabVIEW Virtual Instrument has been completed that accomplishes the rig control plan. Shown in Figure 17, the display panel can be customized to the particular test requirements, alarms, and instrumentation monitoring needs of a particular materials test customer. 


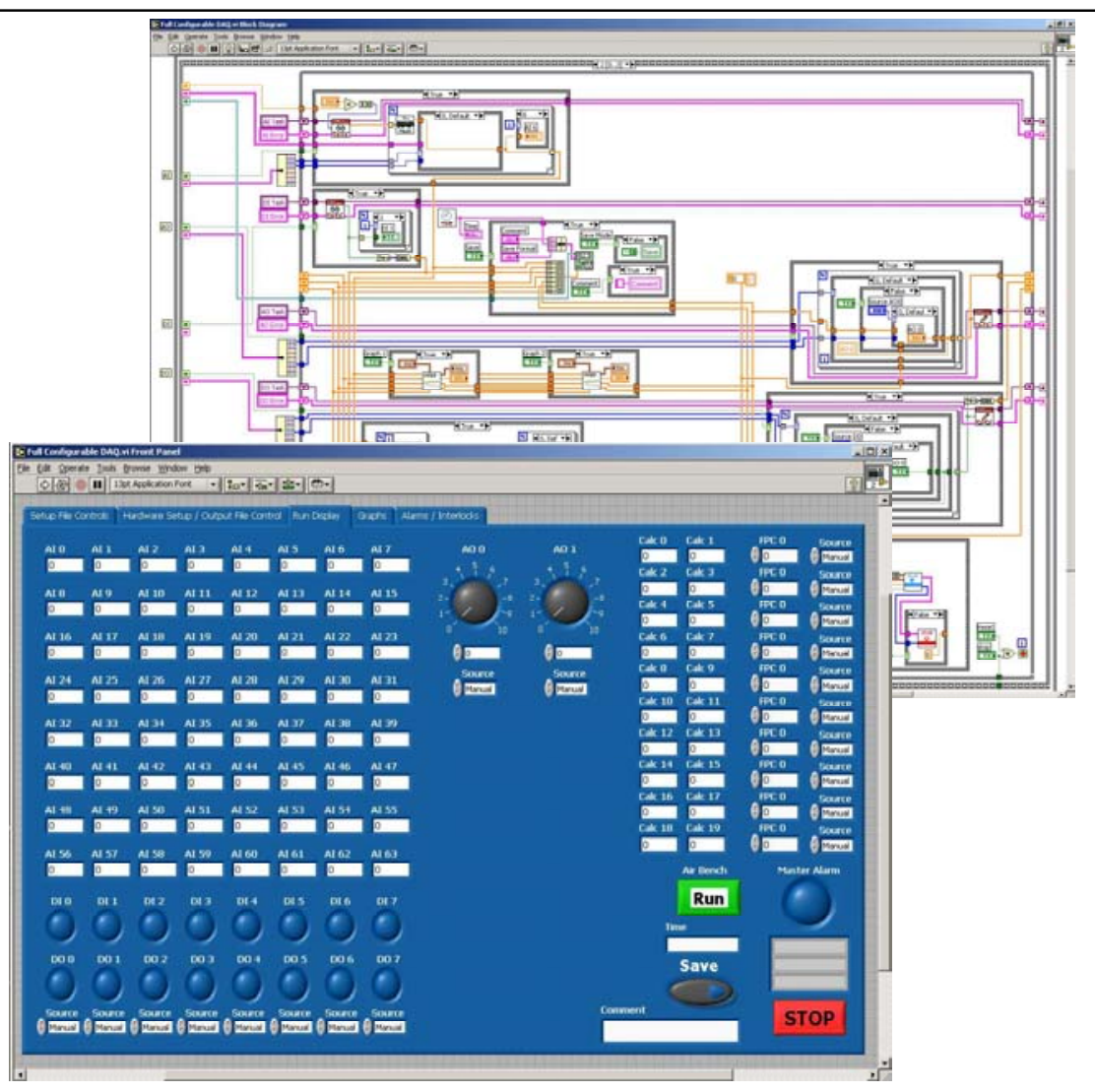

Figure 17. LabVIEW Virtual Instrument Control Panel \& Diagram

\section{$\underline{\text { Rig Performance Analysis Update }}$}

The rig test section and combustor has been sized to allow for a large operating range. Throughout this range the airflow and inlet temperature and pressure are regulated to maintain a constant combustor flow function.

$$
F F=\frac{W \sqrt{T}}{P A_{e}}
$$

Physical flow areas within the combustor are sized to achieve a design pressure loss near $6 \% \mathrm{dP} / \mathrm{P}$ throughout this operating range. Figure 18 shows the results of the analytical flow model simulating nominal operating conditions; 0.365pps airflow @ $350 \mathrm{psi}$ and $775^{\circ} \mathrm{F}$ and $\mathrm{a} 3000^{\circ} \mathrm{F}$ combustor exit temperature. 
See Appendix

Figure 18. Pressure drop and airflow predictions for nominal operating conditions

Material specimens inserted into the test section gaspath can be designed to achieve a broad range of temperature levels and thermal gradients. Figure 19 gives an example of this capability for the case of a nickel base alloy substrate having 0.035 " wall thickness, coated with 0.010" TBC. The external boundary conditions are established by the rig operating condition; rig airflow, pressure and combustor temperature. The internal boundary conditions are established by the rig airflow, inlet temperature and pressure. In addition, the internal geometry of the specimen can be altered by sizing an internal "plug" which changes the cooling air velocity and forces the flow along the inside wall. This example shows that a test specimen fitted with a 0.26 inch diameter plug would experience a TBC surface temperature of $2282^{\circ} \mathrm{F}$ and a bond coat temperature of $1652^{\circ} \mathrm{F}$.

See Appendix

Figure 19. TBC and substrate temperature predictions for a potential specimen design 


\section{$\underline{\text { Rig Energy Cost Update }}$}

Based upon the updated performance analysis for nominal rig operation, rig operating cost was generated based upon current fuel, electricity and labor costs. The results of the analysis shown in Figure 20 assumed that each rig can run 12 specimens simultaneously, and that 1 full-time technician is required for every 3 operational rigs.

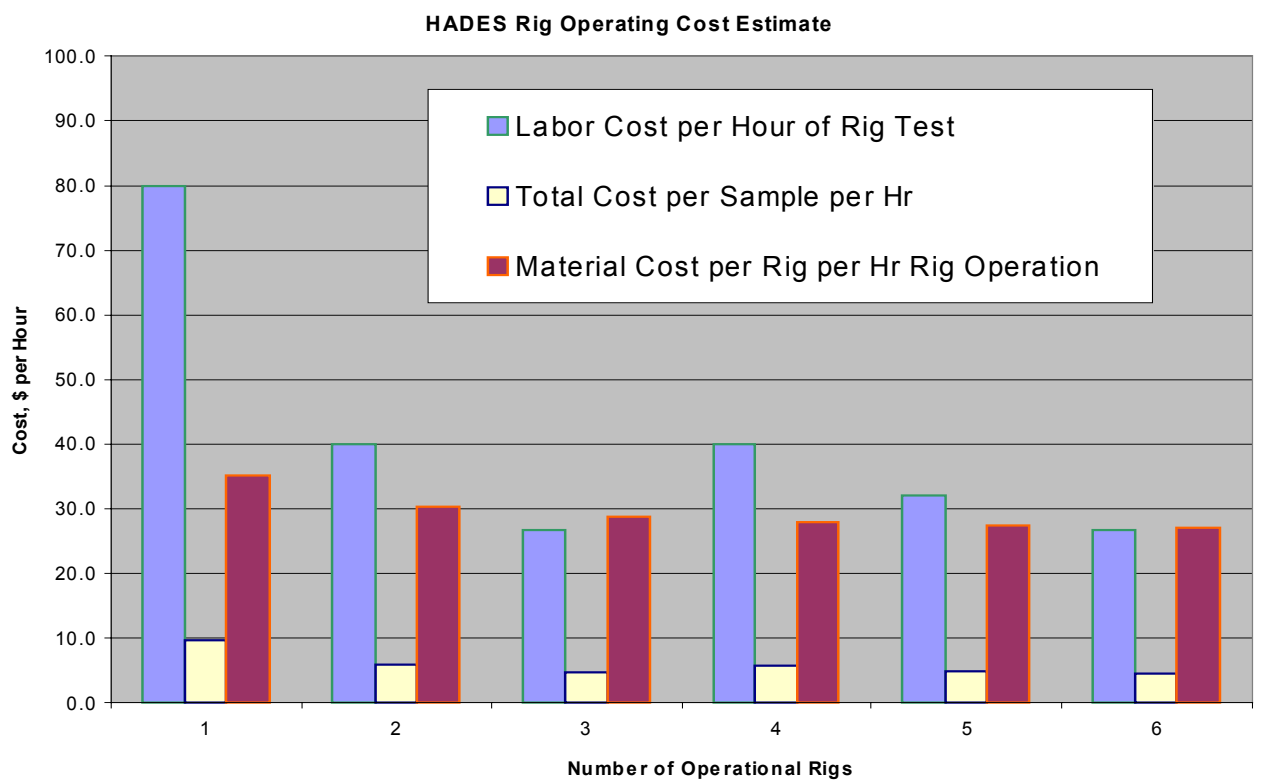

Figure 20. Rig operating cost estimates based on 12 specimens per rig

\section{Detailed Cost Estimate}

A detailed cost estimate was prepared for the prototype rig configuration, as below. Estimates were based on actual costs for similar hardware, with complexity factors applied, as applicable.

\begin{tabular}{|l|rr|}
\hline RIG ASSEMBLY & $\mathbf{\$}$ & $\mathbf{9 7 , 5 8 0}$ \\
\hline COMBUSTOR ASSY & $\$$ & 9,300 \\
\hline HOUSING, TEST SECTION & $\$$ & 3,740 \\
\hline VESSEL, TEST SECTION & $\$$ & 6,969 \\
\hline COVER HALF, VESSEL COOLING & $\$$ & 2,813 \\
\hline PLATE, REAR COVER & $\$$ & 1,118 \\
\hline CASE ASSY, RIG TEST SECTION & $\$$ & 10,800 \\
\hline FUEL NOZZLE ASSY & $\$$ & 2,472 \\
\hline SUPPORT, COMBUSTOR END & $\$$ & 1,265 \\
\hline THREADED DIFFUSER & $\$$ & 1,000 \\
\hline CASE, COMBUSTOR PLENUM & $\$$ & 3,688 \\
\hline DISK SEPARATOR ASSEMBBLY & $\$$ & 3,000 \\
\hline FLANGED COMPARTMENT, ROLLER BEARING & $\$$ & 1,500 \\
\hline STEPPED SHAFT, ROLLER BEARING (HOLES) & $\$$ & 3,500 \\
\hline THRUST PISTON & $\$$ & 2,000 \\
\hline SPLINE ENDED SHAFT, MAG. COUPLING TO PISTON & $\$$ & 2,000 \\
\hline BLIND FLANGE, MAGNETIC COUPLING & $\$$ & 1,000 \\
\hline MAGNETIC COUPLING ASSEMBLY & $\$$ & 5,000 \\
\hline AC DIRECT DRIVE MOTOR & $\$$ & 800 \\
\hline QUENCHING SUPPORT ASSEMBLY & $\$$ & 6,560 \\
\hline HOLLOW SHAFT, THRUST SHAFT & $\$$ & 3,000 \\
\hline
\end{tabular}

\begin{tabular}{|l|lr|}
\hline ANGULAR CONTACT BALL BEARING & $\$$ & 4,683 \\
\hline BALL BEARING COMPARTMENT & $\$$ & 4,000 \\
\hline INNER RACE SUPPORT & $\$$ & 1,500 \\
\hline OUTER RACE SUPPORT & $\$$ & 1,500 \\
\hline 70MM THREADED NUT & $\$$ & 500 \\
\hline 125MM THREADED NUT & $\$$ & 500 \\
\hline FITIING, FLARE TUBE END/MALE PIPE END-AIR & $\$$ & 50 \\
\hline EXHAUST COVER ASSEMBLY & $\$$ & 1,000 \\
\hline PINNED CARBON PISTON RING, DISK SEPARATOR & $\$$ & 600 \\
\hline PINNED CARBON PISTON RING, PISTON & $\$$ & 540 \\
\hline NON CONTACTING CARBON SEAL, BRG. COMPARTMENT & $\$$ & 1,000 \\
\hline O-RING, THRUST COMPARTMENT TO CASE & $\$$ & 200 \\
\hline GASKET, SPRIAL WOUND 8.0 CL 300 & $\$$ & 33 \\
\hline ROPE SEAL, HYBRID WIRE-CERAMIC & $\$$ & 1,000 \\
\hline C-SEAL, COMBUSTOR MOUNT & $\$$ & 1,000 \\
\hline C-SEAL, FUEL NOZZL MOUNT & $\$$ & 2,500 \\
\hline O-RING, VESSEL TO HOUSING LE & $\$$ & 3,000 \\
\hline O-RING, VESSEL TO HOUSING TE & $\$$ & 2,000 \\
\hline O-RING, PLATE TO HOUSING & $\$$ & 200 \\
\hline O-RING, COVER TO HOUSING & $\$$ & 150 \\
\hline O-RING, HOUSING TO CASE & $\$$ & 100 \\
\hline
\end{tabular}




\section{Facility Requirements Definition}

Preliminary specifications were prepared for a building to house the test rigs. Shown in Figure 21, the facility will include test cells, a control room and office space, with auxiliary equipment placed adjacent to the building. The re-scoped program calls for the initial facility to be equipped with three rigs, with the capacity to add more as demand dictates.

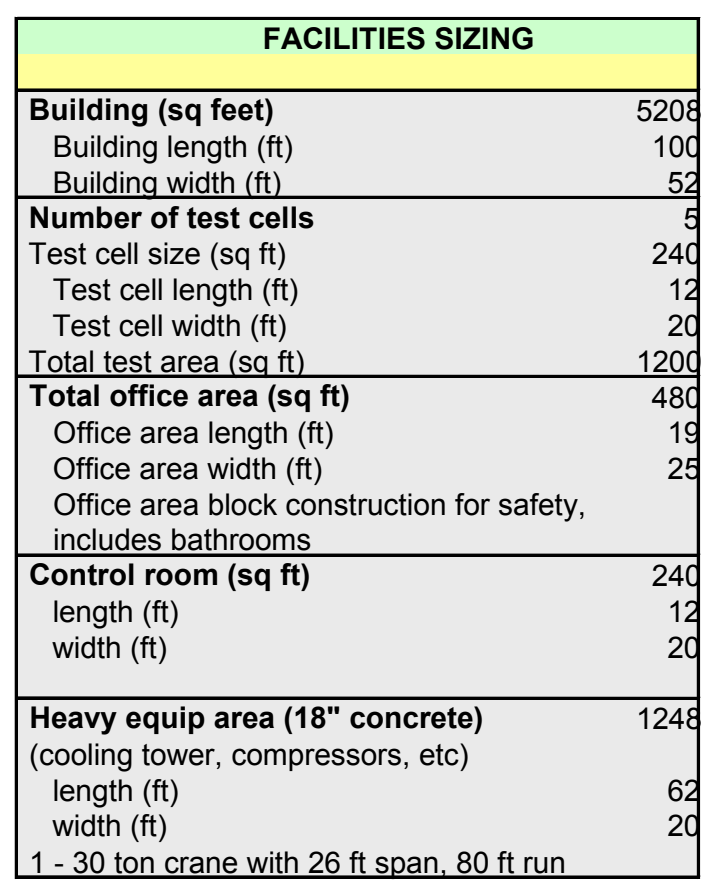

HADES Building

(3 test cells with room for expansion)

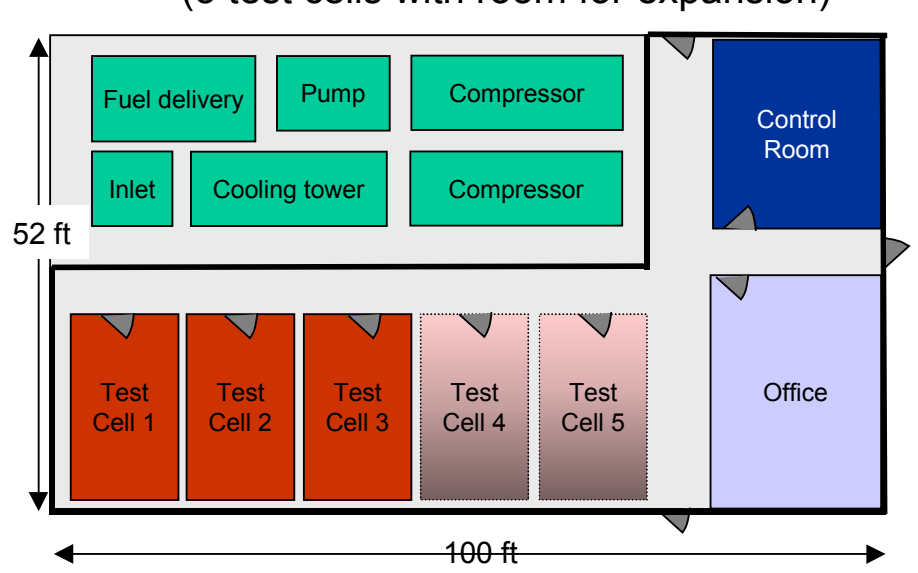

\begin{tabular}{|lrrr|}
\hline Heavy equipment sizes & length (ft) & \multicolumn{1}{c|}{ width (ft) } & area (ft2) \\
\hline primary compressor & 19.5 & 6.8 & 133.25 \\
boost compressor & 18.25 & 6 & 109.5 \\
cooling tower & 15 & 8 & 120 \\
pump skid & 10 & 6 & 60 \\
inlet room & 6 & 6 & 36 \\
fuel delivery skid & 12 & 12 & 144 \\
\hline Total area & & & $\mathbf{6 0 2 . 7 5}$ \\
\hline
\end{tabular}

Figure 21. Preliminary specifications for HADES rig test facility

\section{Permitting Assessment and Plan}

Application for construction permits will be submitted early during Phase $2 \mathrm{~B}$, following a successful prototype rig demonstration test. Four months in the project schedule are allowed for the permit process, followed by 8 months for construction.

A separate emissions permit will not be required for the test facility because it meets North Dakota minor source limits of 100 tons/year for both NOx and CO, based on 6 test cells operating continuously:

NOx@ 50 PPM results in 4.6 tons/year

CO@ $@$ ppm results in 03.tons/year

No hazardous waste permits will be required for test facility operation per Federal Regulation Document 40 CFR 261. 


\section{$\underline{\text { Implementation Plan }}$}

The overall project plan for the HADES test rig is shown in Figure 22. In parallel to this effort is the development of the rig-unique syngas combustor funded under Phase 2 of DOE SBIR grant DE-FG02-03ER83660. FTT has also submitted a proposal to the USAF for an SBIR Phase 2 in which develops a version of the prototype rig capable of subjecting test articles to very high heat flux levels up to $1.5 \mathrm{MBTU} / \mathrm{hr} / \mathrm{ft}^{2}$ at gas temperatures of $4000 \mathrm{~F}$ and 50 bars of pressure. FTT has advised the program managers from both agencies of the synergy between these projects, and of the potential cost savings to the government from using common designs where applicable, testing with the same hardware, conducting prototype testing at the same combustion laboratory, and setting up permanent facilities at the same location.

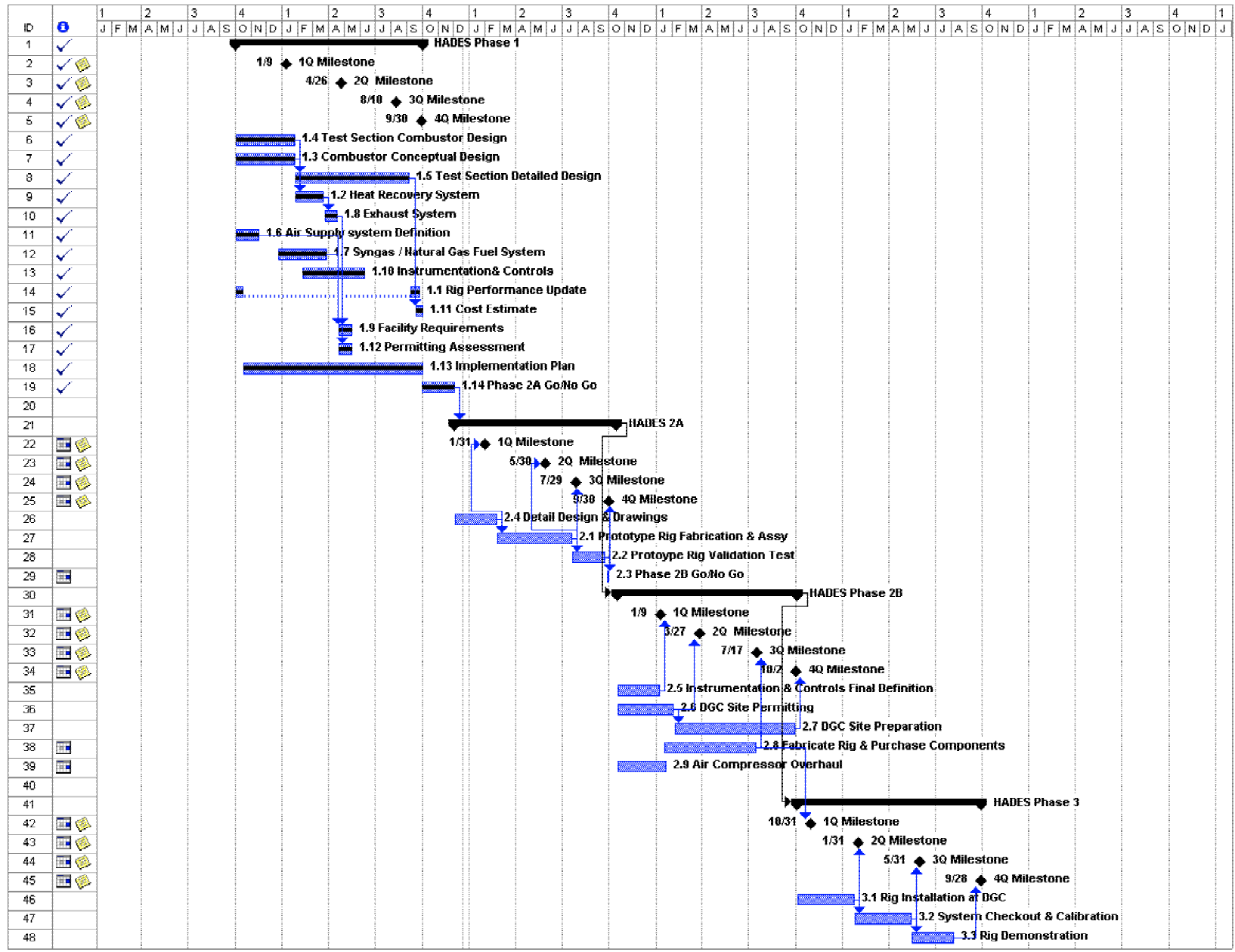

Figure 22. HADES project plan for the DOE Financial Assistance Agreement 


\section{CONCLUSION}

Phase 1 of the Hyperbaric Advanced Demonstration Environmental Simulator (HADES) program has been successfully completed. The results continue to show rig feasibility, both technically and economically. The principle activities during this phase were studies to determine the overall configuration of the rig, detail designs of the rig test section, and updates to the rig performance and cost estimates. Other tasks considered the recovery of waste heat to further reduce rig operating costs, provided preliminary definition of the rig air supply, fuel supply, facility requirements, and rig controls. Implementation planning progressed, with schedules prepared and future project milestones defined. 